\title{
DIAGNOSIS DAN TATALAKSANA HEPATOPULMONARY SYNDROME
}

\author{
Dwitya Elvira
}

\begin{abstract}
Abstrak
Sirosis hepatis dan penyakit hati kronik merupakan penyebab kematian terbanyak di seluruh dunia. Tingginya angka morbiditas dan mortalitas sirosis berhubungan dengan komplikasinya yang bersifat sistemik. Salah satu komplikasi sirosis dapat mengenai paru berupa sindrom hepatopulmonar atau hepatopulmonary syndrome. Hepatopulmonary syndrome (HPS) didefinisikan sebagai trias yang terdiri dari kegagalan hati stadium lanjut, hipoksemia arterial serta dilatasi intravaskular pulmonar tanpa disertai penyakit kardiopulmonar. Patogenesis HPS masih belum diketahui pasti, namun diduga terjadi gangguan metabolisme zat vasoaktif paru yang menimbulkan vasodilatasi vaskuler paru. Manifestasi klinis HPS berupa dispneu yang khas dengan tanda kegagalan hati dan hipertensi portal. Modalitas diagnostik HPS adalah radiologi thorax, analisa gas darah, contrast enhanced echocardiography (CEE), nuclear scanning dengan Tc-99m dan angiografi paru. Penatalaksanaan HPS terutama bertujuan menurunkan vasodilatasi intrapulmonar, meningkatkan oksigenasi arterial dan mengurangi keluhan. Deteksi dini terhadap komplikasi sirosis mutlak diperlukan dalam mencegah dan mengurangi angka morbiditas dan mortalitas.
\end{abstract}

Kata kunci: sirosis hepatis, dispneu, hepatopulmonary syndrome

\begin{abstract}
Liver cirrhosis and chronic liver disease are the leading cause of death worldwide. The high morbidity and mortality associated with their systemic complications. One of the complications of cirrhosis is hepatopulmonary syndrome. Hepatopulmonary syndrome (HPS) is defined as the triad of advanced-stage liver failure, arterial hypoxemia and pulmonary intravascular dilatation without cardiopulmonary disease. The pathogenesis of HPS is still not known for sure, but suspected metabolic disorder pulmonary vasoactive substances that cause pulmonary vascular vasodilatation. The clinical manifestations of HPS is typical dispneu with signs of liver failure and portal hypertension. HPS diagnostic modalities are radiology thorax, blood gas analysis, contrast enhanced echocardiography (CEE), nuclear scanning with Tc-99m and pulmonary angiography. HPS management aims primarily to lower intrapulmonar vasodilation, improving arterial oxygenation and reduce complaints. Early detection of complications of cirrhosis is absolutely necessary in preventing and reducing morbidity and mortality.
\end{abstract}

Keywords: hepatic cirrhosis, dispneu, hepatopulmonary syndrome

Afiliasi Penulis : Bagian IImu Dalam, Fakultas Kedokteran, Universitas Andalas, Padang, Korespondensi : Dwitya Elvira, email : dwitya.elvira@yahoo.com, Telp \HP : 081363102933. 


\section{PENDAHULUAN}

Sirosis hepatis dan penyakit hati kronik merupakan penyebab kematian terbanyak ke-10 pada laki-laki dan ke-12 pada wanita di Amerika Serikat dengan angka kematian mencapai 27.000 tiap tahunnya. Data prevalensi sirosis hepatis di Indonesia dari beberapa pusat pendidikan seperti di RS Dr. Sardjito Yogyakarta melaporkan jumlah pasien sirosis hati berkisar 4,1\% dalam 1 tahun, RS Adam Malik Medan dalam 4 tahun didapatkan pasien sirosis hati sebanyak 4\% dari seluruh pasien di Bagian Penyakit Dalam. Tingginya angka morbiditas dan mortalitas sirosis hepatis berhubungan dengan komplikasinya. Komplikasi sirosis ini bersifat sistemik dan salah satu komplikasinya dapat mengenai paru yang berupa sindrom hepatopulmonar atau hepatopulmonary syndrom (HPS). ${ }^{(1,2)}$

Hepatopulmonary syndrome atau HPS merupakan komplikasi sirosis hepatis pada paru yang ditandai oleh trias yang terdiri dari kegagalan hati stadium lanjut, hipoksemia arterial serta dilatasi vaskular intrapulmonar tanpa disertai penyakit kardiopulmoner yang menyertai. Prevalensi HPS berkisar antara 4-30\% pada penderita sirosis. Studi prospektif terbaru, Pulmonary Vascular of Liver Disease (PVCLD) 33\% pasien sirosis didiagnosis sebagai HPS, dan $40 \%$ pasien calon penerima transplantasi hati mengalami dilatasi vaskular paru. Angka kematian akibat HPS sendiri diperkirakan sebesar $16 \%$ dengan survival rate 2,5 tahun. $(3,4,5)$

Patogenesis pasti HPS masih belum diketahui pasti. Gangguan sintesis dan metabolisme zat vasoaktif paru akibat gangguan hati yang diduga menimbulkan hipoksemia. Manifestasi hipoksemia pada HPS berupa keluhan dispneu yang khas seperti platipneu dan orthodeoxia disertai dengan adanya tanda sirosis, seperti spider naevi, palmar eritem, asites merupakan patognomonis pada HPS. ${ }^{(7,8)}$

\section{METODE}

Artikel ini ditulis berdasarkan hasil penelusuran dan review kepustakaan mengenai sindrom hepatopulmonar sebagai salah satu komplikasi sirosis hepatis. Penelusuran ditekankan pada kriteria diagnosis serta penatalaksanaan sindrom hepatopulmonar.

\section{HASIL DAN PEMBAHASAN}

\section{Definisi}

Sindrom hepatopulmonar atau hepatopulmonary syndrome (HPS) didefinisikan sebagai suatu trias yang terdiri dari kegagalan hati stadium lanjut, hipoksemia arterial $\left(\mathrm{PaO}_{2}<70 \mathrm{mmHg}\right.$ atau gradien oksigen alveolar-arterial $>20$ $\mathrm{mmHg}$ ) serta dilatasi vaskularisasi intrapulmonar, tanpa disertai penyakit kardiopulmoner. HPS merupakan salah satu komplikasi sirosis pada paru yang mempengaruhi pengobatan dan prognosis penyakit serta menjadi penyebab penurunan oksigen darah arterial. Abnormalitas oksigen arterial dapat ditemukan pada pasien dengan gagal hati kronik, namun studi Rao MY et al (2008) memperlihatkan $13,9 \%$ pasien dengan gagal hati kronik mengalami hipoksemia yang disebabkan oleh HPS. $(3,4,9,10,25)$

\section{Epidemiologi Dan Etiologi}

Hubungan antara penyakit hati kronik, sianosis dan clubbing finger pertama kali diperkenalkan oleh Fluckiger tahun 1884 pada seorang wanita 37 tahun dengan gambaran klinis sianosis dan clubbing finger yang ternyata mengalami 
sirosis dan dari pemeriksaan postmortem didapatkan adanya suatu dilatasi vena pulmonar. Berthelot et al (1966) melaporkan adanya perubahan patologis pada vaskularisasi pulmonal penderita sirosis, dimana setelah injeksi suspensi gelatin, ditemukan peningkatan sejumlah cabang-cabang vaskuler perifer akibat vasodilatasi arterial (> $500 \mu \mathrm{m}$ ) yang mempengaruhi lobus bawah paru dan pleura dengan gambaran mirip spider naevi pada kulit, sehingga disebut sebagai spider naevi paru dan pleura. Istilah "intrapulmonary vascular dilatations" pun akhirnya diutarakan oleh Krowka dan Cortese. Baru kemudian, Kennedy dan Knudson, 1977, memperkenalkan "hepatopulmonary syndrome" (HPS) setelah melaporkan pasien sirosis dengan hipoksemia dan ortodeoxia. ${ }^{(11)}$

Prevalensi sindrom hepatopulmonar berkisar antara 4-30\% pada penderita sirosis. Dari studi prospektif, Pulmonary Vascular of Liver Disease (PVCLD) 33\% dari 218 pasien penderita sirosis pada 7 pusat pelayanan medis didiagnosis sebagai HPS, dan sekitar $40 \%$ kandidat transplantasi hati mengalami dilatasi vaskular pulmonar. $(3,10,12)$

Angka kematian akibat HPS diperkirakan sebesar 16\%. Studi retrospektif HPS pada 22 pasien diperoleh angka kematian pada studi ini > $40 \%$ dengan survival rate 2,5 tahun. Beberapa studi memperlihatkan angka survival 5 tahun HPS sebesar 23\% dari 37 pasien yang tidak ditransplantasi hati. Prognosis semakin buruk pada pasien dengan $\mathrm{PaO} 2<50 \mathrm{mmHg}$ pada saat terdiagnosis. ${ }^{(5,10)}$

Etiologi HPS masih belum diketahui dan masih menjadi fokus berbagai penelitian dan debat di kalangan ahli. Pada sejumlah kelompok kecil pasien, penyakit hati berhubungan dengan gambaran parenkim pulmonar yang unik, termasuk granuloma paru atau alveolitis fibrosis pada sirosis bilier primer dan emfisema. Grafik berikut memperlihatkan beberapa penyakit hati yang dapat menyebabkan HPS. Dari grafik tersebut dapat terlihat bahwa hepatitis B, C dan hepatitis kriptogenik merupakan penyebab terjadinya HPS yang terbanyak. $(8,11)$

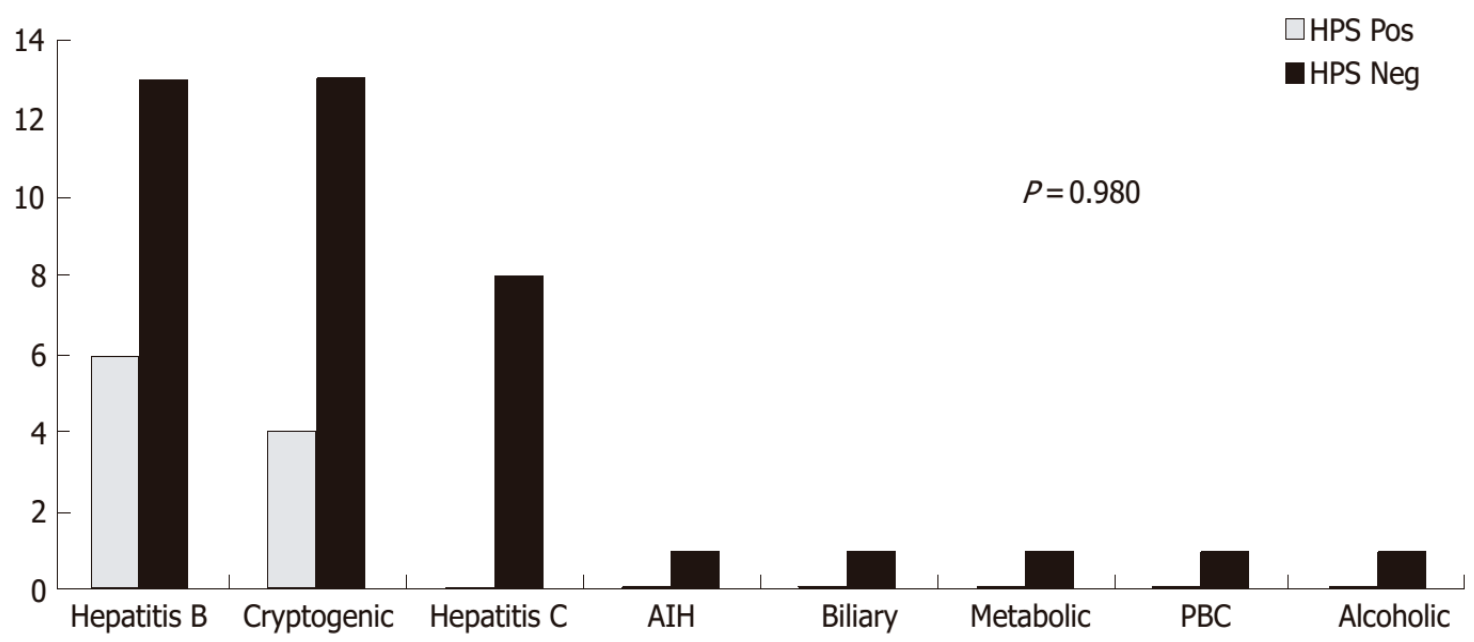

Gambar 1. Etiologi HPS(8) 


\section{Patogenesis}

Patogenesis pasti hepatopulmonary syndrome (HPS) masih belum diketahui pasti. Hipotesis terbaru yang bisa diterima adalah adanya gangguan sintesis dan metabolisme zat vasoaktif paru akibat gangguan hati yang menyebabkan vasodilatasi fungsional vaskuler paru yang menimbulkan hipoksemia. Hal yang unik dari HPS adalah gross dilatation pembuluh darah kapiler dan prekapiler paru (15-100 nm). Otopsi memperlihatkan bahwa subyek dengan HPS mengalami dilatasi alveolar dengan diameter sebesar 60-80 nm, dibandingkan dengan normal 7-15 nm. Dilatasi vaskular intrapulmonar ini terjadi akibat peningkatan produksi atau gangguan klirens hepar terhadap vasodilator atau karena kurangnya produksi atau kurang sensitifnya vaskular paru terhadap vasokonstriktor. ${ }^{(3,6,14)}$

Menurut Castro dan Krowka, ketidakseimbangan antara vasokonstriktor dan vasodilator pada vaskuler pulmonar diduga berkontribusi terhadap patogenesis HPS. Vasodilator yang paling banyak diteliti adalah nitrit oksida (NO), dimana pada HPS ditemukan peningkatan kadar nitrit dan nitrat serta metabolit NO, yang semuanya kembali normal setelah dilakukan transplantasi hati, dengan saturasi oksigen yang juga normal. Pada mencit yang mengalami HPS, terjadi peningkatan protein eNOS (endothelial NO synthase) pada pembuluh darah alveoli paru dan peningkatan aktivitas basal NOS. Diduga ada suatu hubungan yang kuat antara ekspresi eNOS tersebut dengan keparahan HPS. Selain NO, zat vasoaktif lainnya yang berperan dalam patogenesis HPS adalah endothelin-1 (ET-1) dan endothelin B (ETB). ET-1 dapat merangsang efek vasodilator autokrin dengan meningkatkan aktivitas eNOS dan produksi NO melalui reseptor
ETB di sel endotel vaskular, yang menimbulkan vasodilatasi intrapulmonar. Faktor-faktor yang berkontribusi dalam peningkatan ETB diduga disebabkan oleh sirkulasi hiperdinamik akibat peningktan aliran darah pulmonar dan perubahan ekspresi reseptor ETB vaskular, serta peningkatan produksi sitokin, seperti interleukin-1B (IL-1B) dan hipoksia yang merangsang ekspresi ETB. ${ }^{(3,14)}$

Carbon monoksida (CO) merupakan zat vasoaktif yang sedang diteliti peranannya dalam patogenesis HPS. CO menyebabkan vasodilatasi akibat aktifnya jalur cGMP (cyclic guanosine monophosphate), yang secara langsung mengaktivasi saluran $\mathrm{KCa}$. $\mathrm{CO}$ dibentuk saat penghancuran heme oleh heme oksigenase $(\mathrm{HO})$, dimana salah satu proteinnya yaitu $\mathrm{HO}-1$ diekspresikan di alveoli, epitel bronkus, dan sel inflamasi termasuk makrofag. Ekspresi $\mathrm{HO}-1$ ini juga ditemukan meningkat pada sirosis, yang kemungkinan berperan pada patogenesis HPS. Kesimpulan yang sama juga didapat oleh Zhang et al, dimana peningkatan $\mathrm{HO}-1$ tersebut disebabkan oleh penumpukan makrofag intravaskuler pada sirosis yang kemungkinan dirangsang oleh TNF- $\alpha$. $^{(3)}$

\section{Manifestasi Klinis}

Manifestasi klinis utama HPS adalah gangguan oksigenasi yang bervariasi dari ringan sampai berat yang menggambarkan disfungsi hati dan paru. Dispnea merupakan keluhan paling sering dimana menurut Krowka et al, 18\% pasien HPS mengalami sesak nafas, ratarata lama waktu yang diperlukan bagi penderita sirosis untuk mengalami keluhan HPS adalah 4,8 tahun. Penelitian yang dilakukan Alizadeh et al (2006) pada 54 penderita sirosis, 31,5\%-nya didiagnosis sebagai HPS dengan rentang usia 
sekitar 71-80 tahun, dengan keluhan terbanyak adalah dispnea dan sianosis. Sesak nafas dan clubbing finger adalah gejala klinis yang paling sensitif dan spesifik. ${ }^{(3,8)}$

Keluhan yang paling spesifik pada HPS adalah platipnea yaitu keluhan sesak nafas yang dirasakan saat perubahan posisi dari tidur ke berdiri, yang berhubungan dengan orthodeoxia, yaitu penurunan $\geq 4 \mathrm{mmHg} \mathrm{PaO} 2$ atau $\geq 5 \%$ saturasi saat perubahan posisi dari telentang ke berdiri, ditemukan pada $88 \%$ subjek (Krowka et al). Platipnea dan orthodeoxia dengan hipoksemia berat merupakan karakteristik dari HPS. Krowka et al (1990) menjabarkan orthodeoxia ditemukan pada 14 dari 16 pasien (88\%), Eden et al (1996) menemukan orthodeoxia pada 6 pasien sirosis dengan hipoksemia berat, Andrivet et al (1993) menemukan pada 9\% pasien sirosis dengan hipoksemia (rata-rata $\mathrm{PaO} 2<45$ ) saat pasien diberikan oksigen $100 \%$. Meskipun bukan patognomonis, namun adanya temuan ini disertai dengan gangguan hepar yang berat dapat mengarahkan pada diagnosis HPS. Fenomena ini terjadi oleh karena abnormalitas vaskuler dominan berlokasi di lapangan tengah dan bawah paru; efek gravitasi dapat meningkatkan aliran darah yang dapat memperburuk ketidakcocokan antara ventilasi-perfusi dan akhirnya menimbulkan gangguan oksigenasi arterial saat pasien berada dalam posisi berdiri. ${ }^{(14,15)}$

\section{Diagnosis}

Pendekatan diagnosis HPS melibatkan pemeriksaan objektif terhadap 3 komponen trias HPS. Trias HPS tersebut sesuai dengan kriteria pada tabel berikut. ${ }^{(13)}$

1. Liver Dysfunction or Portal Hypertension

- Cirrhosis

- Non-cirrhotic portal hypertension

(e.g. portal vein thrombosis, nodular regenerative hyperplasia, Budd-Chiari Syndrome)

- Acute fulminant hepatitis

- Allograft rejection

2. Abnormal Gas-Exchange

- Alveolar-arterial gradient $\left(\mathrm{AaDO}_{2}\right) \geq 20 \mathrm{mmHg}$ (at rest, in the standing position)

3. Intrapulmonary Vascular Dilatation

- Contrast echocardiography delayed shunt ( $>3$ heartbeats)

- Technetium-99 macroaggregated albumin total body scanning

Gambar 2. Trias Diagnosis Hepatopulmonary Syndrome ${ }^{(13)}$

Untuk memulainya, gangguan hati atau hipertensi portal harus dibuktikan melalui imaging abdomen termasuk ditemukannya sirosis, tanda hipertensi portal seperti varises esofagus dan atau splenomegali, selanjutnya pemeriksaan laboratorium fungsi hepar untuk mengkonfirmasi sirosis. ${ }^{(13)}$
Beberapa algoritma telah dikembangkan dalam mendiagnosis HPS. ${ }^{13}$ salah satunya seperti yang diperlihatkan oleh gambar 3 . 


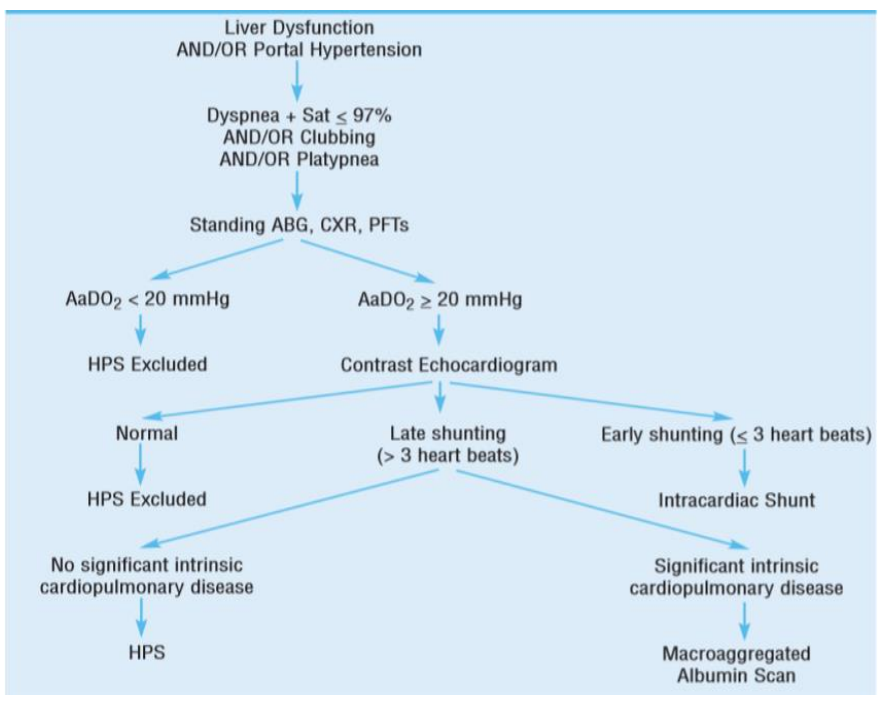

Gambar 3. Algoritme Diagnosis HPS(13)

Dalam menentukan telah terjadinya dilatasi vaskular intrapulmonar pada HPS, dapat digunakan beberapa alat diagnostik sebagai berikut:

\section{Foto radiologi thorax}

Radiologi thorax memperlihatkan gambaran vaskular paru yang prominen di lobus bawah bilateral paru, namun temuan ini tidak spesifik. Berikut gambaran radiologi thorax pada pasien diduga HPS. ${ }^{(16,17)}$

Gambar 4. Gambaran Radiologi Thorax pada Penderita HPS ${ }^{(16)}$

2. Pemeriksaan analisis gas darah diper-lukan dalam menentukan diagnosis HPS. Pulse oksimetri merupakan metode pemeriksaan yang paling mudah dan praktis digunakan. Saturasi oksigen > 96\% memiliki sensitivitas $100 \%$ dan spesifisitas $88 \%$ dalam mendeteksi $\mathrm{PaO} 2<70$ $\mathrm{mmHg}$ dan dapat digunakan sebagai arahan diagnosis HPS. ${ }^{(10)}$

\section{Contrast Enhanced Echocardiography} (CEE) merupakan alat diagnostik yang sensitif dalam mendiagnosis pintas intrapulmonar. CEE ini menggunakan saline agitated atau indocyanine green yang membentuk gelembung mikro dengan ukuran 15 $\mu \mathrm{m}$ yang diinjeksikan intravena. Dalam keadaan normal, gelembung mikro ini terperangkap dalam vaskularisasi paru dan diserap. Namun pada pasien dengan pintas intrakardiak dan intrapulmonar, mikrobuble ini dapat juga ditemukan pada jantung kiri setelah beberapa lama. Pada pintas intrakardiak kanankiri, bubble ini muncul di jantung kiri 3 kali denyut jantung setelah muncul di jantung kanan. Pada pintas intrapulmonar, bubble ini muncul setelah denyut jantung ke 4-6.(18) Penelitian Krowka et al berupa studi prospektif terhadap 38 kandidat transplantasi hati dimana CEE digunakan, $\quad 13,2 \%$ didiagnosis sebagai HPS, sementara Hopkins et al dengan 53 pasien penyakit hati berat menyatakan bahwa HPS ditemukan pada $47 \%$ pasien sirosis. ${ }^{(18)}$

4. Nuclear scanning dengan $99 \mathrm{~m}$ Technetium macroaggregated albumin (Tc-99m MAA) merupakan metode kedua dalam diagnosis HPS. Macro-aggregated albumin dengan ukuran $20 \mu \mathrm{m}$ seharusnya terperangkap pada kapiler paru (diameter 8-15 $\mu \mathrm{m}$ ), namun bila hasil scan memperlihatkan adanya uptake 
radionuklide oleh ginjal, otak atau keduanya menandakan adanya pintas intrapulmonar/ intra-kardiak. Pada pasien normal, hanya $3-6 \%$ yang melewati paru. Wolfe et al mendokumentasikan bahwa pada pasien sirosis dengan hipoksemia berat $10-71 \%$ melewati paru. ${ }^{(16,17)}$

5. Angiografi paru merupakan metode invasif, sehingga jarang digunakan. Berdasarkan angiografi paru ini, HPS diklasifikasikan menjadi 2 tipe, tipe I dan tipe II. Pada tipe I, diperoleh dilatasi arteri pulmonar prekapiler tanpa fistula arteriovenous dengan bentuk normal sampai difus, bentuk spider atau spongy. Pasien tipe I ini mengalami hipoksemia berat dan responnya buruk terhadap oksigen $100 \%$. Sementara pada tipe II, terjadi fistula arteri-vena paru yang terlokalisir. Tipe ini tidak terlalu sering ditemukan, sama sekali tidak berespon terhadap pemberian oksigen $100 \%$ dan indikasi untuk dilakukan terapi embolisasi. ${ }^{16,19)}$ Modalitas diagnostik yang terbaru adalah CT scan thorax resolusi tinggi dan evaluasi terhadap pulmonary blood transit time. Namun perlu dilakukan penelitian skala besar dalam meng-gunakan potensinya dalam mendiag-nosis HPS. ${ }^{(19)}$

\section{Tatalaksana}

\section{Diet Dan Modifikasi Gaya Hidup}

Belum ada penelitian atau studi tentang diet atau modifikasi gaya hidup pada pasien dengan HPS. Pembatasan konsumsi alkohol dan obat hepato-toksik, yang juga merupakan pengoba-tan penyakit hati juga perlu dipertim-bangkan. Semua pasien sirosis, khu-susnya dengan
HPS harus menjalani diet rendah garam (2 g) untuk mengurangi retensi cairan dan overload. Pengaturan olahraga juga menjadi tantangan pada HPS, terutama yang berat. Pada pasien dengan HPS yang mendapat terapi oksigen dosis rendah jangka panjang, olahraga ringan dibolehkan dengan memper-tahankan saturasi oksigen $90 \%$ selama olahraga. ${ }^{(21)}$

\section{Terapi Farmakologi}

Tujuan terapi farmakologi adalah menurunkan vasodilatasi intrapul-monar, meningkatkan oksigenasi arterial dan mengurangi keluhan. Belum ada studi kasus kontrol dalam menentukan terapi yang efektif pada HPS. Terapi oksigen diperlukan untuk mengurangi keluhan dan meningkatkan kemampuan beraktivitas. Oksigen 2-5 l/menit melalui nasal kanul, dengan mempertahankan saturasi oksigen $90 \%$ pada saat istirahat dan beraktivitas diindikasikan pada penderita HPS. ${ }^{(22,23)}$

\section{Terapi Pembedahan}

Tujuan terapi pembedahan pada HPS adalah untuk mengembalikan ke keadaan yang mendasari terkait dengan perkembangan sindrom ini (sirosis dan hipertensi portal). Transplantasi hati merupakan terapi satusatunya pada HPS, berdasarkan adanya perbaikan analisis gas darah dan resolusi komplit pada lebih dari $85 \%$ pasien. ${ }^{(23)}$

\section{Terapi Lain}

Transjugular intrahepatic portosystemic shunt (TIPS). Sejumlah laporan kasus memperlihatkan penggunaan TIPS sebagai tatalaksana pasien 
HPS. Meskipun beberapa memperlihatkan adanya perbaikan klinis, namun sebagian lagi tidak. Pada beberapa studi, TIPS memperlihatkan adanya efek samping pada fungsi hepar dan terjadinya ensefalopati. ${ }^{(22)}$

\section{Coil Embolization of Vascular Dila- tation}

Pada salah satu laporan kasus, dikatakan bahwa coil embolization dapat memperbaiki $\mathrm{PaO}_{2}$ pada pasien post transplantasi hati dengan prolonged hipoksemia. Penelitian lain juga memperlihatkan bahwa coil embolization dapat digunakan sebagai terapi paliatif pada pasien yang akan dilakukan transplantasi hati. (22)

Beberapa penelitian terhadap terapi farmakologi HPS masih dilakukan, yaitu pentoksifiline, bosentan dan inhaled N-nitro-L-arginine methyl ester yang efektif pada uji eksperimental pada manusia dan hewan coba. Terapi ini merupakan terapi yang cukup menjanjikan, namun masing-masingnya memiliki efek samping dan harus dievaluasi dengan uji klinis. ${ }^{(23,24)}$

\section{SIMPULAN}

Sirosis hati atau penyakit kronik memiliki berbagai komplikasi yang bersifat sistemik, dan dapat mengenai paru yang disebut sebagai sindrom hepatopulmonar atau hepatopulmonary syndrome (HPS). Hepatopulmonary syndrome (HPS) didefinisikan sebagai suatu trias yang terdiri dari kegagalan hati stadium lanjut, hipoksemia arterial $(\mathrm{PaO} 2<70$
$\mathrm{mmHg}$ ) serta dilatasi vaskuler intrapulmonar dengan manifestasi klinis yang khas berupa dispneu, platipneu dengan orthodeoxia disertai tanda disfungsi hati. Dalam mendiagnosis HPS dapat dilakukan pemeriksaan radiologi thorax, contrast enhanced echocardiography (CEE), Tc-99m MAA serta angiografi paru. Penatalaksanaan HPS berupa pemberian oksigen, terapi empiris terhadap penyakit hatinya, serta transplantasi hati. Deteksi dini terjadinya komplikasi sirosis ini diperlukan dalam mengurangi tingginya angka morbiditas dan morta-litas akibat penyakit ini.

\section{DAFTAR RUJUKAN}

1. Anderson RN, Smith BL. Deaths: leading causes for 2001. National Vital Statistic Reports: from the Centers for Disease Control and Prevention. 2003;52(9):1-85.

2. Nurdjanah S. Sirosis hati. Dalam: Buku Ajar IImu Penyakit Dalam Jilid III. Jakarta 2009;445-448.

3. Wang YW, Lin HC. Recent advances in hepatopulmonary syndrome. J Chin Med Assoc 2005;68(11):500-505.

4. Nunes $\mathrm{H}$, Lebrec D, Mazmanian M, Capron $\mathrm{F}$, Heller J, Tazi K. Role of nitric oxide in hepatopulmonary syndrome in cirrhotic rats. Am J Resp Crit Care Med. 2001;164:879885.

5. Anel R, Sheagren J. Novel presentation and approach to management of hepatopulmonary syndrome with use of antimicrobial agents. CID 2001:32:131-136.

6. Lange $P$, Stoller J. The hepatopulmonary syndrome. Ann Intern Med 1995;122:52129.

7. Lange P, Stoller JK. Hepatopulmonary syndrome. Diakses dari www.uptodate.com Maret 2012.

8. Alizadeh A, Fatemi S, Mirzaee V, Khoshbaten M, Talebipour B, Sharifian A. Clinical features of hepatopulmonary syndrome in cirrhotic patients. World $\mathrm{J}$ Gastroenterol 2006;12(12):1954-1956.

9. Almoosa K. The hepatopulmonary syndrome. Hospital Physician 2000:23-30. 
10. Varghese J. Ilias-basha $H$, Dhanasekaran R, Singh S, Venkataraman J. Hepatopulmonary syndrome-past to present. Annals of Hepatology 2007;6(3):135-142

11. Zakim \& Boyer's Hepatology A Textbook of Liver Disease. Boyer T, Manns M, Sanyal A. 2012 Saunders Elsevier Philadelphia.

Chapter 23. Pulmonary Complications in Patients with Liver Disease.394-399. Moises I, Nevah R, Fallon M.

12. Adams P, Erasmus J, Crockett R, Mitchell J, Godwin JD, McDermott V. The hepatopulmonary syndrome: radiologic finding in 10 patients. AJR 1996;166:13791385.

13. Gupta S. The hepatopulmonary syndrome: a common pulmonary complication of liver disease. Ontario Thoracic Reviews. 2009;18.

14. Roisin RR, Krowka MJ. Current concepts hepatopulmonary syndrome-a liver induced lung vascular disorder. $N$ Eng $J$ Med 2008;358(22):2378-2388.

15. Hoeper M, Krowka M, Strassburg C. Portopulmonary hypertension and hepatopulmonary syndrome. Lancet 2004;363:1461-68.

16. Leung A. Case 63: the hepatopulmonary syndrome. Radiology 2003;229:64-67.

17. Miki K, Shinohara T, Ogushi F, Sone S, Yamada H, Oishi Y. Hepatopulmonary syndrome-discussion of cardiopulmonary parameters. The Journal of Medical Investigation 2000;47:164-69.
18. Lee $\mathrm{CH}$, Cheng ST. Shortness of breath while sitting up: hepatopulmonary syndrome. CMAJ, January 11, 2011;183(1)

19. Sawant $P$,Vashishtha C, Nasa M. Management of cardiopulmonary complications of cirrhosis. Int'l Journ of Hepatology 2011;1-11.

20. Cremona G, Higenbottam TW, Mayoral V, Alexander G, Demoncheaux E, Borland C. Elevated exhaled nitric oxide in patients with hepatopulmonary syndrome. Eur Respir J. 1995,8,1883-1885.

21. Fleming G, Cornell T, Welling T, Magee J, Annich G. Hepatopulmonary syndrome: use of extracorporeal life support for lifethreatening hypoxia following liver transplantation. Liver Transpl 14:966-970, 2008.

22. Arguedas M, Fallon M, Hepatopulmonary syndrome. Current treatment options in gastroenterology 2005,8:451-6.

23. Aboussonan LS, Stoller JK. The hepatopulmonary syndrome. Baillieres Best Pract Res Clin Gastroenterol 2000;14(6):1033-48.

24. Zhang J, Ling Y, Tang L, Luo B, Chacko B, Patel RP. Pentoxifylline attenuation of experimental hepatopulmonary syndrome. J Appl Physiol 2007;102:949-955.

25. Rao MY, Raghu J, Deshmukh S, Amaravathi KS, Sudir V. Arterial hypoxemia in patients with cirrhosis of liver. J Assoc Physicians India.2008;56;68 